\title{
Effect of silica fume/binder ratio on compressive strength development of reactive powder concrete under two curing systems
}

\author{
Mohammed Abed ${ }^{1}$, Mohammed $\mathrm{Nasr}^{1,{ }^{*}}$ and Zaid Hasan ${ }^{1}$ \\ ${ }^{1}$ Babylon Technical Institute, Al-Furat Al-Awsat Technical University, 51015, Babylon, Iraq
}

\begin{abstract}
This paper aims to investigate the influence of Silica fume proportion ratio in respect to the total amount of binder on compressive strength of reactive powder concrete cured in two curing systems. Four ratios of Silica fume $(0 \%, 15 \%, 25 \%$ and $35 \%)$ as replacement of cement weight were considered. After demolding, two curing systems were used: the first included immersing the cubic specimens in water at $24 \pm 2$ ${ }^{\circ} \mathrm{C}$ until the test. In the second, the specimens were immersed in hot water at $105 \pm 5{ }^{\circ} \mathrm{C}$ (accelerated curing) for 48 hours, then in water at $24 \pm 2{ }^{\circ} \mathrm{C}$ until the test. The results show that mix which contains $25 \%$ Silica fume imparts more enhancement on compressive strength as compared to the control mix. Also, it was found that the second system of curing has more influence on compressive strength development than the first one, especially at earlier ages.
\end{abstract}

\section{Introduction}

Reactive powder concrete (RPC) that was developed in Paris in 1990 is a special type of concrete that has two main properties: high strength and high performance. The gradation in its materials gives a low percent of voids with high density when compared with traditional concrete [1]. Coarse aggregate is absent in reactive powder concrete, therefore, the microstructure is far from non-homogenous between the cementitious materials and fine aggregate [2].

Different curing systems were applied in the literature in the production of RPC. For activity accelerating, heat treatment may be adopted to improve the microstructure and enhancing the earlier strength of RPC when silica fume is used in the mix [3]. Talebinejad et al. [4] indicated that the heat curing at $(90-200)^{\circ} \mathrm{C}$ modified the pozzolanic activity, while, Cheyrezy et al. [5] showed that heat curing was essential at $(200-250){ }^{\circ} \mathrm{C}$ for getting excellent compressive strength, especially at earlier ages. Treatment using static pressure was also used and led to enhance the compressive strength by about 33\% in comparison to others without the static pressure [6]. A study by Yazic et al. [7], found that some reduction in bonding (paste and fiber) happened after using of autoclave and steam curing when compared with normal curing.

The goal of this study is to investigate the influence of silica fume/ binder ratio on compressive strength of RPC using two curing systems: accelerated and normal curing. Additionally, due to that previous work [8] showed that the smaller the maximum particle size and the better the packing degree of fine aggregate, the higher the compressive strength of RPC, so, sand with a maximum grain size of $0.3 \mathrm{~mm}$ is used to achieve the aim of this study.

\section{Experimental Program}

\subsection{Materials}

Ordinary Portland cement, commercially called "Kar", was used in this study. The chemical composition of the cement, which conforms to Iraqi specifications No.5/1984 [9], is illustrated in Table 1. Silica fume purchased from "BASF" company was used as a pozzolanic material, see Table 2 . Natural sand with single size $(0.15-0.3 \mathrm{~mm})$ was used as fine aggregate. In order to enhance workability, third generation superplasticizer (Gelnium 54), based on polycarboxylic ether was added.

\subsection{Mix proportions, mixing and casting}

A total of four mixes were made to achieve the goals of this investigation. Three of them include replacing of cement (by weight) with silica fume in proportions of $15 \%, 25 \%$, and $35 \%$. The other mix, without adding, was considered as control. The sand/ binder and water/ cementitious ratios for all mixes were $1: 1$ and 0.18 , respectively. The details of mix proportions per one cubic meter are shown in Table 3.

Due to the low water content and high cementitious materials that are usually used in reactive powder concrete, it required relatively a long mixing time. The depended mixing procedure in this research was as follows:

*Corresponding author: msn_alamar@yahoo.com 
- All dry materials were fed into the mixer and mixed at a low-speed rate $(140 \mathrm{r} / \mathrm{min})$ for one minute;

- The mixing water and superplasticizer, which were previously mixed, were then added, and the all materials were mixed for one minute at low-speed rate;

- After that, the mixer was stopped for one minute and the speed was changed to a moderate rate $(285 \mathrm{r} / \mathrm{min})$;

- Then, the mixer was operated at this rate for eight minutes.

After the mixing was complete, the fresh RPC was placed in standard cube molds. The following casting and tamping procedures were as described by ASTM C109 standard [10].

Table 1. Chemical composition of cement.

\begin{tabular}{|c|c|c|}
\hline $\begin{array}{c}\text { Oxides } \\
\text { Composition }\end{array}$ & $\begin{array}{c}\text { Content, } \\
\%\end{array}$ & $\begin{array}{c}\text { Iraqi } \\
\text { specifications } \\
\text { (No.5/1984), \% }\end{array}$ \\
\hline $\mathrm{CaO}$ & 61.8 & - \\
\hline $\mathrm{SiO}_{2}$ & 20.3 & - \\
\hline $\mathrm{Al}_{2} \mathrm{O}_{3}$ & 4.16 & - \\
\hline $\mathrm{Fe}_{2} \mathrm{O}_{3}$ & 3.9 & - \\
\hline $\mathrm{MgO} \mathrm{SO}_{3}$ & 3.4 & $<5$ \\
\hline Free lime & 2.4 & $<2.5$ \\
\hline L.O.I. & 0.03 & - \\
\hline L.S.F. & 0.96 & $0.66-1.02$ \\
\hline Insoluble residue & 1 & $<1.5$ \\
\hline \multicolumn{2}{|c|}{} \\
\hline
\end{tabular}

Table 2. Properties of silica fume.

\begin{tabular}{|c|c|}
\hline Property & $\begin{array}{c}\text { Value or } \\
\text { description }\end{array}$ \\
\hline Unit weight & $2300 \mathrm{~kg} / \mathrm{m}^{3}$ \\
\hline Fineness (blain) & $>15 \mathrm{~m}^{2} / \mathrm{g}$ \\
\hline $\mathrm{SiO}_{2}$ & $>85 \%$ \\
\hline $\mathrm{CaO}$ & $<1 \%$ \\
\hline Chloride content & $<0.1 \%$ \\
\hline Activity index & $112 \%$ \\
\hline
\end{tabular}

Table 3. Details of mix proportions.

\begin{tabular}{|c|c|c|c|c|c|}
\hline $\begin{array}{c}\text { Mix } \\
\text { symbol }\end{array}$ & $\begin{array}{c}\text { Cement, } \\
\mathbf{k g} / \mathbf{m}^{\mathbf{3}}\end{array}$ & $\begin{array}{c}\text { Silica fume, } \\
\mathbf{k g} / \mathbf{m}^{\mathbf{3}} \mathbf{( \% )}\end{array}$ & $\begin{array}{c}\text { Sand, } \\
\mathbf{k g} / \mathbf{m}^{\mathbf{3}}\end{array}$ & $\begin{array}{c}\text { Water, } \\
\mathbf{k g} / \mathbf{m}^{3}\end{array}$ & $\begin{array}{c}\text { Superplasticize } \\
\mathbf{r , \%} \text { of binder }\end{array}$ \\
\hline M0 & 1150 & 0 & 1150 & 207 & 2.58 \\
\hline M15 & 977.5 & $172.5(15)$ & 1150 & 207 & 2.58 \\
\hline M25 & 862.5 & $287.5(25)$ & 1150 & 207 & 2.58 \\
\hline M35 & 747.5 & $402.5(35)$ & 1150 & 207 & 2.58 \\
\hline
\end{tabular}




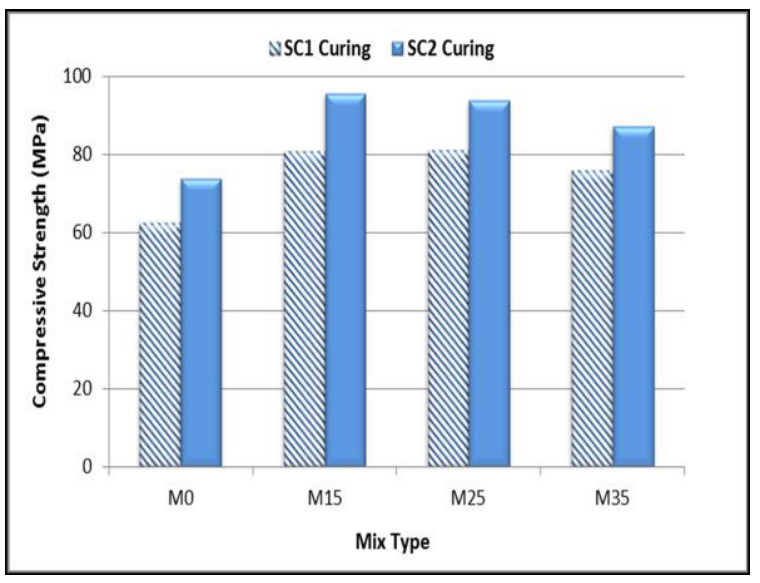

Fig. 1. Compressive strength results at 7 days.

led to increasing the early strength [11]. Similar behavior was also found in the literature [12]. Furthermore,

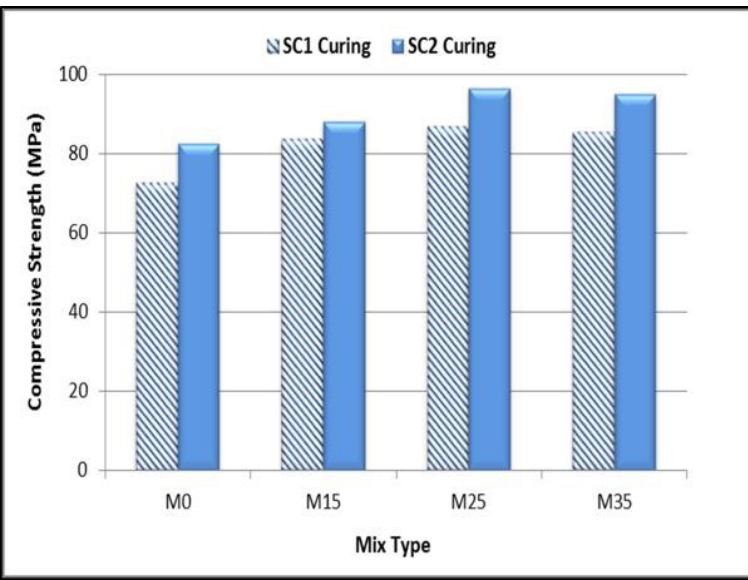

Fig. 2. Compressive strength results at 14 days.

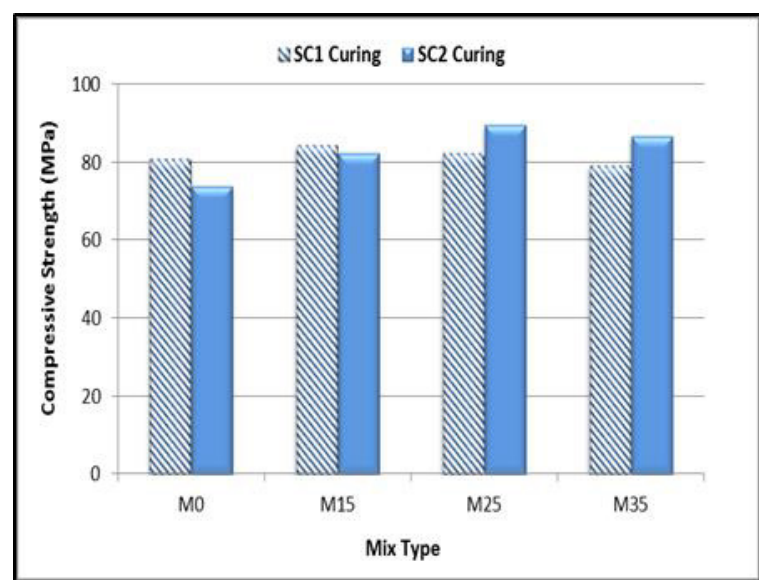

Fig. 3. Compressive strength results at 28 days

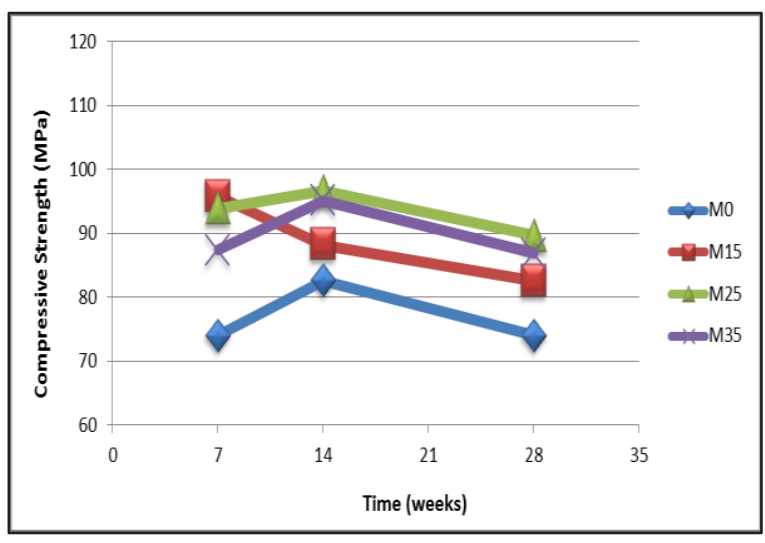

Fig. 4. Compressive strength development with time (accelerated curing system).

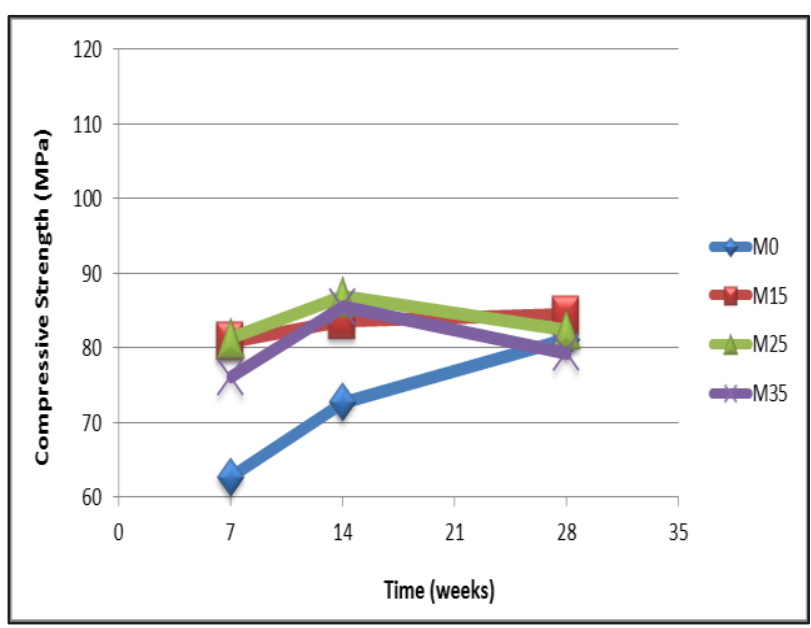

Fig. 5. Compressive strength development with time (normal curing system). 
though that compressive strength showed higher initial values at early ages ( 7 and 14 days), it tended to decrease at later ages (28 days), but it remained higher than control mix. At 28 days, for M0 and M15 mixes, compressive strength values of the normal curing system (SC1) were higher than that in the SC2 system. Also, the influence of accelerating curing (SC2) was more pronounced for higher replacements of silica fume $(25 \%$ and $35 \%$ ) than that for lower replacement $(15 \%)$.

Figures 4 and 5 illustrate the compressive strength development with time for all mixes. It can be seen that, for accelerated curing systems (Figure 4), all mixes except M15 showed strength increasing at 14 days age in comparison with beginning age (7 days) then tended to decrease at the later age (28 days). This action could result from the non-homogeneous distribution of hydration products within the matrix due to the accelerated effect of hot water curing that caused, finally, the strength to be decreased at later ages. On the other hand, the M15 mix showed permanent decrease with time for all considered ages. For normal curing system (Figure 5), the results revealed that control and M15 mixes had a comparable exhibition, continual increase in strength with time. However, the other mixes (M25 and M35) showed similar behavior as for the accelerated curing system.

\section{Conclusions}

Based on the results of this investigation, the following conclusions can be obtained:

1. Replacing of cement with silica fume up to $35 \%$ enhances the compressive strength of RPC, but in different rates with time.

2. The best compressive strength result, for $\mathrm{SC} 1$ and SC2 curing, is obtained when replacing of cement by $25 \%$ of silica fume.

3. The influence of accelerated curing is more obvious on strength development of RPC at early ages than later ages, especially for M25 and M35 mixes.

4. The influence of SC2 curing becomes more clarity at $25 \%$ and $35 \%$ replacements of silica fume than that for $15 \%$.

\section{References}

1. Rahmatabadi M.A.D., Int. J. Struct. Civ. Eng. Res., Vol. 4, No. 4, pp. 354-358, (2015)

2. Sujatha T. and Basanthi D., IJEAR, Vol. 4, Issue: spl -2, pp. 85-87, (2014)

3. Sumith K.K., Gururaj A., and Siddesh R.K.M., JETIR, Vol. 2, Issue: 6 pp. 1749-1757, (2015)

4. Talebinejad I., Bassam S.A., Iranmanesh A. and Shekarchizadeh M., International Symposium on Ultrahigh Performance Concrete, pp.133-41, (2004)

5. Cheyrezy M., Maret V. and Frouin L., Cem. Concr. Res., Vol. 25, No. 7, pp. 1491-1500, (1995)

6. Helmi M., Hall M.R., Stevens L.A. and Rigby S.P., Cons. Build. Mat., Vol. 105 pp. 554-562, (2016)

7. Yazıc H., Yardimc M.Y., Aydın S., and Karabulut A.S., Cons. Build. Mat., Vol. 23, pp. 1223-1231, (2009)

8. Zhu Z., Li B., Liu J. and Lv X., Trans Tech Publications, Vols. 548-549, pp. 247-253, (2014)

9. Iraqi Standard Specifications No. 5, Portland Cement, Central Organization for Standardization and Quality Control, Iraq, (1984)

10. ASTM C 109/C 109M - 13, Standard Test Method for Compressive Strength of Hydraulic Cement Mortars (using 2-in. or [50-mm] cube specimens), ASTM, West Conshohocken, PA, USA, (2013)

11. Yunsheng Z., Wei S., Sifeng L, Chujie C., Jianzhong L., Cem. Concr. Comp., Vol. 30, pp. 831-838, (2008)

12. Arel H.S., Vol. 6, pp. 664-674, (2016) 